Eur. J. Clin. Chem. Clin. Biochem.

Vol. 29, 1991, pp. 477-480

(C) 1991 Walter de Gruyter \& Co. Berlin - New York

\title{
Influence of Pregnancy on Dipeptidyl Peptidase IV Activity (CD 26 Leukocyte Differentiation Antigen) of Circulating Lymphocytes
}

\author{
By R. Mentlein ${ }^{1}, R$. Staves ${ }^{2}$, Hella Rix-Matzen ${ }^{3}$ and H.-R. Tinneberg ${ }^{2 *}$ ) \\ 1 Anatomisches Institut \\ 2 Frauenklinik \\ 3 Biochemisches Institut \\ Universität Kiel, Germany
}

(Received November 5, 1990/Mai 27, 1991)

Summary: Dipeptidyl peptidase IV (CD 26 leukocyte differentiation antigen) is an enzymic surface marker of a human $T$ lymphocyte subpopulation which has been shown to be associated with their capacity to produce large amounts of interleukin 2 and proliferate strongly in response to mitogenic stimulation. The peptidase activity on the surface of purified human peripheral mononuclear cells was determined spectrophotometrically with the substrate glycyl- $L$-proline-4-nitranilide. The peripheral mononuclear cells of pregnant women exhibited depressed mean dipeptidyl peptidase IV activity when compared with the activity of peripheral mononuclear cells from non-pregnant or male individuals. The gestational age ( 7 to 20 weeks) of the pregnant collective had no effects on peptidase levels. Women taking oral contraceptives had a slightly lower mean activity than the non-pregnant group not using contraceptives. Thus, reduced dipeptidyl peptidase IV activity of peripheral mononuclear cells might reflect impairement of cellular immunity during pregnancy.

\section{Introduction}

The immunoregulatory proceșeses operating during pregnancy, which might explain the survival of the fetus as an allograft, are not fully understood. Many observations suggest that cell mediated immunity is depressed (1). Several groups, investigating the cellular basis of pregnancy-induced impairment of cellular immunity, have reported conflicting findings on the distribution of circulating $\mathrm{T}$ and $\mathrm{B}$ lymphocytes throughout normal pregnancies. While some groups observed a decrease of the level of T-cells and an increase of the level of B-cells $(2-5)$, others could not detect significant differences $(6,7)$. More recently variations of the T-cell subsets have been investigated during pregnancy. Using monoclonal antibodies some workers found a significant decrease in relative and absolute numbers of circulating OKT $4+$ cells during gestation $(5,8)$. It is well accepted that these cells comprise the T-helper-cell subset, and therefore their reduction may explain the weaker cell-mediated responsiveness during pregnancy and contribute to the lack of maternal rejection of the fetus. However, other workers have not been able to confirm this finding $(7,9,10)$.

All of the studies mentioned above used monoclonal antibodies to estimate the changes of T-cell subpopulations. Because of these controversial results, a different approach to the investigation of the alterations of the T-cell subpopulations during pregnancy was chosen. Dipeptidyl peptidase IV ${ }^{1}$ ) (EC 3.4.14.5) is an ectoenzyme which liberates dipeptides from the

1) Enzymes: Dipeptidyl peptidase IV, dipeptidyl aminopeptidase IV (EC 3.4.14.5); dipeptidyl peptidase II (EC 3.4.14.2); aminopeptidase P (EC 3.4.11.9); prolyl aminopeptidase (EC 3.4.11.5)

*) Present address: Universitäts-Frauenklinik Tübingen, W-7400 Tübingen 1, Germany 
amino terminus of peptides or chromogenic substrates provided that the penultimate residue is a proline (11, for review). Within the haemopoietic system, this peptidase is only expressed on the plasma membrane of $T$ lymphocytes (12). About $10-60 \%$ of T-cells from human peripheral blood bear this enzyme. Peptidasepositive cells were found in both $\mathrm{CD} 4+$ and $\mathrm{CD} 8+$ lymphocytes (13). It has recently been shown that CD 26 antigen is represented by the ectoenzyme dipeptidyl peptidase IV (14). Expression on T lymphocytes was found to be associated with their capacity to produce large amounts of interleukin 2 and to proliferate strongly in response to mitogenic stimulation (13). Although this enzyme seems to play a role during activation of $T$ lymphocytes $(15,16)$, its precise biological function on lymphocytes is unknown. We report here an approach to the quantitative evaluation of the alterations of cell mediated immunity caused by pregnancy, based on measurement of the dipeptidyl peptidase IV activity of peripheral blood cells, thereby taking advantage of the restricted specificity of this enzyme.

\section{Materials and Methods}

Study collective

The blood donors were all healthy individuals who were classified into four groups. Nineteen women with pregnancies ranging from 7 to 20 weeks gestation with a mean age of $24.2 \pm 5.4$ years (range: $17-37$ years), were compared against three control groups: 11 non-pregnant women taking oral contraceptives (mean age $26.6 \pm 4.6$; range $22-38$ years), 6 non-pregnant women who were not using any contraceptives (mean age 28.2 \pm 8.1 ; range $22-44$ years), and 10 males (mean age $32.4 \pm 3.7$; range $25-38$ ).

\section{Lymphocyte preparation}

Sterilized preservative-free sodium "heparin ( $50 \mathrm{IU} / 10 \mathrm{ml}$ blood) was placed in sterile polystyrol $16 \mathrm{ml}$ Falcon tubes (Becton Dickinson, Heidelberg, Germany) into which $10 \mathrm{ml}$ of freshly collected blood was immediately transferred and mixed. Human peripheral mononuclear blood cells were isolated by a one step centrifugation over Lymphoflot $(\mathrm{d}=1.077 \mathrm{~kg} / \mathrm{l}$ Biotest, Dreieich, Germany) after diluting the whole blood 1:2 with Hank's balanced salt solution adjusted to $\mathrm{pH}$ 7.3. No attempts were made to remove monocytes. The peripheral mononuclear cells were washed twice with salt solution and following the last centrifugation were resuspended in $700 \mu l$ salt solution. The peripheral mononuclear cells concentration was then determined using a TOA Microcell counter (CC-108, Colora MeBtechnik, Lorch, Germany). Enzyme activity of the suspension was determined within $3 \mathrm{~h}$ after isolation.

Enzyme assay

Dipeptidyl peptidase IV activity was estimated spectrophotometrically with Gly-Pro-4-nitranilide by a modification of the procedure of Nagatsu et al. (17). One hundred microlitres of $2 \mathrm{mmol} / 1$ Gly-Pro-4-nitranilide (Bachem, Bubendorf, Switzerland) in water, $100 \mu \mathrm{l}$ of $0.5 \mathrm{~mol} / 1 \mathrm{Tris} / \mathrm{HCl}$-buffer, $\mathrm{pH} 8.0$, containing $5 \mathrm{mmol} / \mathrm{l} \mathrm{EDTA}$ and $600 \mu \mathrm{l}$ water were prewarmed at $37^{\circ} \mathrm{C}$ in a thermostatically regulated micro-cuvette. After mixing $200 \mu \mathrm{l}$ of the suspension with washed peripheral mononuclear cells (containing a measured number of lymphocytes within the range $2-4 \times 10^{6}$ cells), the increase in absorbance versus a blank (peripheral mononuclear cells replaced by salt solution) was recorded at $405 \mathrm{~nm}$ for $15-20 \mathrm{~min}$. Enzyme activity was calculated from linear changes in absorbance with time (usually reached after $1-3$ min) using molar absorbance of $990 \mathrm{~m}^{2} / \mathrm{mol}$ for the liberated 4-nitrophenol. One unit (U) corresponds to the release of $1 \mu \mathrm{mol}$ 4-nitrophenol per min under the above conditions. Measurements were made in triplicate for each patient.

\section{Statistical analysis}

Normal distribution was checked by the Kolmogoroff-Smirnowtest. Statistical differences between the groups were calculated with the t- and a modified t-test (18).

\section{Results}

The dipeptidyl peptidase IV activities of peripheral mononuclear blood cells from pregnant, non-pregnant and male individuals are summarized in table 1. For pregnant women with pregnancies of gestational ages ranging between 7 to 20 weeks there were no significant differences in the peptidase IV activity of peripheral mononuclear cells. The mean activity level for this group is therefore given as an overall mean, irrespective of gestational age. Individual dipeptidyl peptidase IV values as well as the mean and median catalytic activity concentration for each group is shown graphically in figure 1. Differences between the pregnant and all other groups are apparent and can be sustained by statistical analysis (tab. 1). The most significant differences wैere found between preg-

Tab. 1. Mean and median dipeptidyl peptidase IV activities of human peripheral mononuclear blood cells.

\begin{tabular}{|c|c|c|c|c|c|}
\hline \multirow[t]{2}{*}{ Group } & \multirow[t]{2}{*}{ Type } & \multirow[t]{2}{*}{$\mathbf{n}$} & \multicolumn{2}{|c|}{$\begin{array}{l}\text { Dipeptidyl peptidase } \\
\text { IV activity } \\
\text { (mU/10 cells) }\end{array}$} & \multirow{2}{*}{$\begin{array}{l}\text { Statistical } \\
\text { difference } \\
\text { against } \\
\text { population }^{2} \text { ) }\end{array}$} \\
\hline & & & Mean \pm SD & Median & \\
\hline I & Pregnant & 20 & $0.35 \pm 0.09$ & 0.30 & II, III, IV \\
\hline II & $\begin{array}{l}\text { Non-preg- } \\
\text { nant, } \\
\text { contracep- } \\
\text { tive }\end{array}$ & 11 & $0.46 \pm 0.08$ & 0.46 & I \\
\hline III & $\begin{array}{l}\text { Non-preg- } \\
\text { nant, } \\
\text { no contra- } \\
\text { ceptive }\end{array}$ & 6 & $0.53 \pm 0.09$ & 0.49 & I \\
\hline IV & Male & 18. & $0.44 \pm 0.06$ & 0.43 & I \\
\hline
\end{tabular}

a) Statistical differences were calculated by using the t-test. The significance level in all cases was at least $>99 \%$ (I compared with III $>99.9 \%$ ). According to the Kolmogroroff-Smirnowtest normal distribution within the groups and the total collective is given at the $95 \%$ level. 
nant women and non-pregnant ones taking no contraceptive. Table 1 and figure 1 include only the data from healthy individuals. Activities greater than 2 standard deviations above the peptidase mean activity of the pregnant group were found for a pregnant woman (30th day of cycle) who aborted 4 days after measurement $\left(0.60 \mathrm{mU} 10^{-6}\right.$ peripheral mononuclear cells), for a pregnant women after amnionocentesis (16 weeks; $0.76 \mathrm{mU} 10^{-6}$ peripheral mononuclear cells), and for one with abdominal pains taking paracetamol $\left(0.83 \mathrm{mU} 10^{-6}\right.$ peripheral mononuclear cells). Within the non-pregnant group, values much lower than the mean were obtained from a woman (0.32 mU $10^{-6}$ peripheral mononuclear cells) undergoing immunization against typhus and cholera and from another woman with repeated bleeding within a particular cycle $\left(0.29 \mathrm{mU} 10^{-6}\right.$ peripheral mononuclear cells). It is therefore essential to carefully screen individuals and to obtain follow-ups on the outcome of pregnancy for example.

It is essential to measure the dipeptidyl peptidase IV activity of peripheral mononuclear cells within $2-5 \mathrm{~h}$ after purification. The cells should be stored at room temperature, since a decrease in activity was observed after storage at $4{ }^{\circ} \mathrm{C}$. The coefficient of variance of the enzymic test method was determined to be $10 \%$. The dipeptidyl peptidase IV activity of the serum was completely removed from the peripheral mononuclear cells by the washing procedure, since no activity could be detected in the supernatant of the second wash. As already reported (12), lysis of peripheral mononuclear cells with $1 \%$ Triton $X-100$ does not increase the peptidase activity, indicating that almost all activity is expressed on the cell surface.

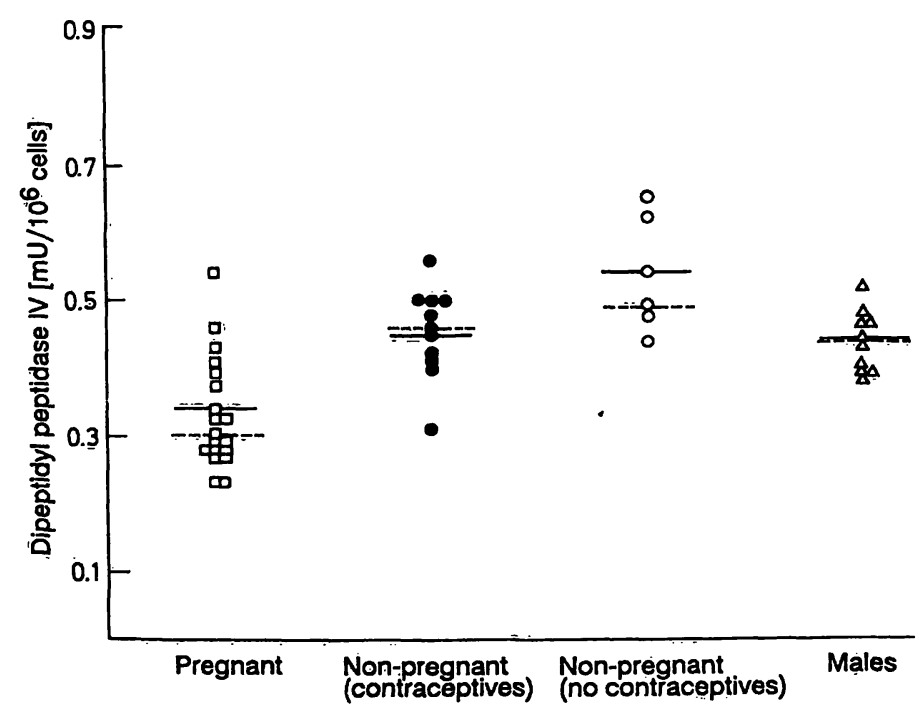

Fig. 1. Dipeptidyl peptidase IV activity of human peripheral mononuclear blood cells from pregnant, non-pregnant and male individuals (mean activity $\longrightarrow$, median activity --.-). The non-pregnant women are divided into those taking oral contraceptives or no contraceptives.

\section{Discussion}

Glycyl- $L$-proline-4-nitranilide is hydrolysed by mononuclear cells isolated from human blood exclusively by dipeptidyl peptidase IV under the conditions employed (19). Dipeptidyl peptidase ${ }^{1}$ ) II, which competes for the hydrolysis of this substrate, is inhibited by the slight alkaline $\mathrm{pH}$ and the presence of Tris during the incubation (20); the only other proteases acting on this substrate, namely aminopeptidase $\mathrm{P}^{1}$ ) and prolyl aminopeptidase $^{1}$ ) by sequential action, are inhibited by EDTA (11). Replacement of the above chromogenic substate by a fluorogenic one (-2-naphthylamide or -4-methylcoumarin) increases the sensitivity, but requires a stirred spectrofluorometer (21). It is essential to remove serum completely before measuring the dipeptidyl peptidase IV activity of peripheral mononuclear cells, since serum contains considerable activity. It is not known whether serum dipeptidyl peptidase IV originates from lymphocytes, endothelial cells of blood vessels or other tissues. However, serum dipeptidyl peptidase IV activity is also reduced in the first trimester of pregnancy (22).

Measurement of dipeptidyl peptidase IV activity of peripheral mononuclear cells should reflect either the number of circulating peptidase $+/ C D 26+T$ lymphocytes or a variation of the expression of this protein on the lymphocyte subset. Activity and antigen expression appear to correlate (16). In clinical studies, dipeptidyl peptidase IV immunoreactivity or activity of peripheral mononuclear cells has been used as a $\mathrm{T}$ lymphocyte marker of leukaemias $(19,23)$ or human immunodeficiency virus infections (24). As compared with the variations found in these diseases or caused by infections (this study), the reduction of dipeptidyl peptidase IV activity of peripheral mononuclear cells during pregnancy is rather low. Comparing the data of non-pregnant women taking or taking not contraceptives, peptidase activity on peripheral mononuclear cells appears to be hormonally influenced. However, provided that the dipeptidyl peptidase IV/CD 26 subset of lymphocytes or the increase of this marker mirrors activated lymphocytes, as suggested by others $(13-16)$, the decrease of peptidase activity on peripheral mononuclear cells can be interpreted as a quantitative correlate for the depressed cellular immunity in pregnancy. Apart from this, dipeptidyl peptidase IV on peripheral mononuclear cells appears to be an interesting parameter for monitoring the status of cellular immunity in other diseases.

\section{Acknowledgement}

We thank Dr. Werner Butte, Universität Oldenburg, for his valuable help in statistical analysis of the data. 


\section{References}

1. Beer, A. E. \& Billingham, P. (1971) Immunobiology of Mammalian Reproduction. Adv. Immunol. 14, 1-84.

2. Strelkauskas, A. J., Wilson, B. S., Dray, S. \& Dodson, M. (1975) Inversion of Levels of Human T and B Cells in Early Pregnancy. Nature 258, 331-332.

3. Blumer, R. \& Hancock, K. W. (1977) Depletion of Circulating $\mathrm{T}$ Lymphocytes in Pregnancy. Clin. Exp. Immunol. $28,302-305$.

4. Strelkauskas, A. J., Davies, J. \& Dray, S. (1978) Longitudinal Studies Showing Alterations in the Levels and Functional Response of T and B Lymphocytes in Human Pregnancy. Clin. Exp. Immunol. 32, 531-539.

5. Vanderbeeken, Y., Vlieghe, M. P., Delespesse, G. \& Duchateau, J. (1982) Characterization of Immunoregulatory T Cells During Pregnancy by Monoclonal Antibodies. Clin. Exp. Immunol. 48, 118-120.

6. Scott, J. R. \& Feldbusch, T. L. (1978) T- and B-Cell Distribution in Pregnancy. J. Am. Med. Asss. 239, 27692771.

7. Lucivero, G., Selvaggi, L., Dell'osso, A., Antonaci, S., Iannone, A., Bettocchi, S. \& Banomo, L. (1983) Mononuclear Cell Subpopulations During Normal Pregnancy: I. Analysis of Cell Surface Markers using Conventional Techniques and Monoclonal Antibodies. Am. J. Reprod. Immunol. 4, 142-145.

8. Sridama, V., Pacini, F., Yang, S.-L., Mowad, A., Reilly, M. \& De Groot, L. J. (1982) Decreased Levels of Helper T Cells. A Possibile Cause of Immunodeficiency in Pregnancy. New Eng. J. Med. 1982, 352-356.

9. Moore, M. P., Carter, N. P. \& Redman, C. W. G. (1983) Lymphocyte Subsets in Normal and Pre-eclamptic Pregnancies. Br. J. Obstetrics Gynecol. 90, 326-331.

10. Coulam, C. B., Silverfield, J. C., Kazmar, R. E. \& Fathman, C. G. (1983) T-Lymphocyte Subsets During Pregnancy and the Menstrual Cycle. Am. J. Reprod. Immunol. 4, 88-90.

10. Coulam, C. B., Silverfield, J. C., Kazmar, R. E. \& Fathman, C. G. (1983) T-Lymphocyte Subsets During Pregnancy and the Menstrual Cycle. Am. J. Reprod. Immunol. 4, 88-90.

11. Mentlein, R. (1988) Proline Residues in the Maturation and Degradation of Peptide Hormones and Neuropeptides. FEBS Lett. 234, 251-256.

12. Mentlein, R., Heymann, E., Scholz, W., Feller, A. C. \& Flad, H.-D. (1984) Dipeptidyl Peptidase IV as a New Surface Marker for a Subpopulation of Human T-Lymphocytes. Cell. Immunol. 89, 11-19.

13. Scholz, W., Mentlein, R., Heymann, E., Feller, A. C., Ulmer, A. J. \& Flad, H.-D. (1985) Interleukin 2 Production by Human $T$ Lymphocytes Ídentified by Antibodies to Dipeptidyl Peptidase IV. Cell. Immunol. 93, 199-211.
14. Ulmer, A. J., Mattern, T., Feller, A. C., Heymann, E. \& Flad, H.-D. (1990) CD 26 Antigen is a Surface Dipeptidyl Peptidase IV as Characterized by Monoclonal Antibodies Clone T II-19-4-7 and 4E11C7. Scand. J. Immunol. 31, $429-435$.

15. Schön, E., Demuth, H.-E., Eichmann, E., Horst, H.-J., Körner, I.-J., Kopp, J., Mattern, T., Neubert, K., Noll, F., Ulmer, A. J., Barth, A. \& Ansorge, S. (1989) Dipeptidyl Peptidase IV in Human T Lymphocytes: Impaired Induction of Interleukin 2 and gamma Interferon Due to Specific Inhibition of Dipeptidyl Peptidase IV. Scand. J. Immunol. 29, 127-132.

16. Hegen, M., Niedobitèk, G., Klein, E., Stein, H. \& Fleischer, B. (1990) The T Cell Triggering Molecule Tp103 is Associated with Dipeptidyl Aminopeptidase IV Activity. J. Immunol. 144, 2908-2914.

17. Nagatsu, T., Himo, M., Fuyamada, H., Hayakawa, T., Sakakibara, S., Nakogawa, Y. \& Takemoto, T. (1976) New Chromogenic Substrates for X-Prolyl Dipeptidylaminopeptidase. Analyt. Biochem. 74, 466-476.

18. Sachs, L. (1984) Angewandte Statistik, 6th edn., pp. 209215 and pp. 256-258, Springer Verlag, Berlin.

19. Schön, E., Demuth, H. U., Barth, A. \& Ansorge, S. (1984) Dipeptidyl Peptidase IV of Human Lymphocytes. Evidence for Specific Hydrolysis of Glycylproline p-Nitroanilide in T-Lymphocytes. Biochem. J. 223, 255-258.

20. Mentlein, R. \& Struckhoff, G. (1989) Purification of Two Dipeptidyl Aminopeptidases II from Rat Brain and Their Action on Proline-Containing Neuropeptides. J. Neurochem. 52, 1284-1293.

21. Sedo, A., Krepela, E. \& Kasafirek, E. (1989) A Kinetic Fluorometric Assay of Dipeptidyl Peptidase IV in Viable Human Blood Mononuclear Cells. Biochimie 71, 757-761.

22. Krepela, E., Kasafirek, E., Vicar, J. \& Kraml, L. (1983) An Assay for Dipeptidyl Peptidase IV Activity in Human Serum and Serum of Pregnant Women with Glycyl-L-Proline-l-Naphthylamide and Other Glycyl-L-Proline-Arylamides as Substrates. Physiol. Bohemoslov. 32, 334-345.

23. Scott, C. S., Stark, A. N., Minowado, J. \& Drexler, H. G. (1988) Quantitative and Qualitative Studies of Leukaemic Cell Dipeptidylpeptidases II and IV. Leukemia Res. 12, $129-134$.

24. DePasquale, A., Ginaldi, L., Limoncelli, P. \& Quaglino, D. (1989) Dipeptidyl Amino Peptidase IV Cytochemistry in Circulating Lymphocytes from HIV-I-Seropositive Subjects. Acta Haematol. $81,19-21$.

Rolf Mentlein

Anatomisches Institut

der Universität Kiel

Olshausenstraße 40

W-2300 Kiel

Bundesrepublik Deutschland 